\title{
Leiomyosarcoma of small intestine
}

INSERM

\section{Source}

INSERM. (1999). Orphanet: an online rare disease and orphan drug data base.

Leiomyosarcoma of small intestine. ORPHA:104076

Small bowel leiomyosarcoma is a rare type of small bowel malignancy, originating in the smooth muscle cells within the muscularis propria or the muscularis mucosa, most often found in the jejunum, and presenting with gastrointestinal bleeding and anemia and sometimes with other non-specific symptoms such as vomiting, nausea, abdominal pain and weakness and spreading to regional lymph nodes in $14 \%$ of cases. 